\title{
PARN wt Allele
}

National Cancer Institute

\section{Source}

National Cancer Institute. PARN wt Allele. NCI Thesaurus. Code C152102.

Human PARN wild-type allele is located in the vicinity of $16 p 13.12$ and is approximately $197 \mathrm{~kb}$ in length. This allele, which encodes poly(A)-specific ribonuclease PARN protein, plays a role in the positive regulation of mRNA decay and telomere synthesis. Mutation of the gene is associated with telomere-related pulmonary fibrosis and/or bone marrow failure type 4 and autosomal recessive dyskeratosis congenita type 6 . 